University of Nebraska - Lincoln

DigitalCommons@University of Nebraska - Lincoln

Publications from USDA-ARS / UNL Faculty

U.S. Department of Agriculture: Agricultural

Research Service, Lincoln, Nebraska

2017

\title{
Methylation of hemoglobin to enhance flocculant performance
}

Matthew Essandoh

USDA-ARS, Matthew.Essandoh@ars.usda.gov

Rafael A. Garcia

USDA-ARS, rafael.garcia@ars.usda.gov

Gary D. Strahan

USDA-ARS, gary.strahan@ars.usda.gov

Follow this and additional works at: https://digitalcommons.unl.edu/usdaarsfacpub

Essandoh, Matthew; Garcia, Rafael A.; and Strahan, Gary D., "Methylation of hemoglobin to enhance flocculant performance" (2017). Publications from USDA-ARS / UNL Faculty. 1764.

https://digitalcommons.unl.edu/usdaarsfacpub/1764

This Article is brought to you for free and open access by the U.S. Department of Agriculture: Agricultural Research Service, Lincoln, Nebraska at DigitalCommons@University of Nebraska - Lincoln. It has been accepted for inclusion in Publications from USDA-ARS / UNL Faculty by an authorized administrator of DigitalCommons@University of Nebraska - Lincoln. 


\title{
Methylation of hemoglobin to enhance flocculant performance
}

\author{
Matthew Essandoh, ${ }^{a^{*}}$ Rafael A Garcia ${ }^{a}$ and Gary D Strahan ${ }^{b}$
}

\begin{abstract}
BACKGROUND: Synthetic organic polymer flocculants can be highly effective at clarifying suspensions, but these substances may also have negative environmental and health effects. Relatively few studies have been done using biobased flocculants, which are more environment friendly. Hemoglobin $(\mathrm{Hb})$ has previously been demonstrated to be a promising flocculant of kaolin and lignin suspensions. This study examines the methylation of $\mathrm{Hb}$ side chain carboxyl groups for the purpose of improving its flocculation performance at near-neutral $\mathrm{pH}$.

RESULTS: Potentiometric titration of methylated $\mathrm{Hb}(\mathrm{MeHb})$ showed an approximately $28 \%$ degree of methylation when the $\mathrm{Hb}$ was suspended in methanol with $0.8 \mathrm{~mol} \mathrm{~L}^{-1} \mathrm{HCl}$ for $48 \mathrm{~h}$. Under some conditions, MeHb clarified suspensions of kaolin at one-quarter the dose that was required for $\mathrm{Hb}$. Furthermore, MeHb exhibited flocculant activity over a wide $\mathrm{pH}$ range, compared with $\mathrm{Hb}$. The percentage of original turbidity removed was $37 \%$ for $\mathrm{Hb}$ while $60 \%$ of the original turbidity was removed for MeHb at near-neutral $\mathrm{pH}(\mathrm{pH}=6.8)$.
\end{abstract}

CONCLUSIONS: Very small doses of methylated hemoglobin (MeHb) rapidly clarify suspensions of kaolin. The potential of MeHb as a biobased flocculant for the clarification of water for industrial or municipal use was demonstrated.

Published 2017. This article is a U.S. Government work and is in the public domain in the USA.

Keywords: hemoglobin; bioflocculant; methylation; water treatment; kaolin

\section{INTRODUCTION}

Flocculants are substances which aid water clarification by causing suspended particles to aggregate and later settle. They are used in several industrial fields including wastewater treatment, mineral extraction, agricultural irrigation, and land management. Polyacrylamide (PAM) and its derivatives are among the most widely used synthetic polymer flocculants. However, PAM's monomer (acrylamide) and other degradation products are highly mutagenic and carcinogenic, and sometimes lead to low microbial activity in activated sludge. ${ }^{1,2}$ Also, the use of PAM-based flocculants can lead to the build-up of acrylamide concentrations in sludge basins. ${ }^{3}$ Environmental persistence of synthetic polymers is well known. It is therefore not surprising that various concerns have been raised across the globe against the use of synthetic organic polymeric flocculants (SOPF), especially PAM. ${ }^{4}$ Biobased flocculants may be effective substitutes for PAM.

Annually, approximately 2 million tons of animal blood are produced in the US as a by-product from slaughterhouses. ${ }^{5}$ Blood has a high concentration of the protein hemoglobin $(\mathrm{Hb})$ and $\mathrm{Hb}$ is easily isolated from whole blood. $\mathrm{Hb}$ has been shown to be a very effective flocculant of kaolin and lignin suspensions, at relatively low doses. ${ }^{6}$ A major drawback of $\mathrm{Hb}$-flocculant is that its performance drops off rapidly as the $\mathrm{pH}$ increases above 5.5 . Expanding the $\mathrm{pH}$ window beyond $\mathrm{pH} 5.5$ would enhance the utility of $\mathrm{Hb}$ as a bio-based substitute for PAM.

Although methylation of proteins has been reported often in the literature, relatively little research has been performed on methylated proteins as flocculants. The flocculation of diatomite by methylated egg albumin and soy protein have been reported. ${ }^{7,8}$
Clay particles (kaolin) have a negative charge and are made primarily of silicate. The negative charges cause the clay particles to repel each other, preventing them from aggregating. Proteins, however, have both positive and negative charged groups exposed to the solvent. Reducing the amount of negatively charged groups on a protein may increase the attraction between the protein and negatively charged particles. Methylation of the hemoglobin to eliminate the carboxylic acid groups will increase the basicity and the net positive charges on the surface of the hemoglobin which can lead to enhanced flocculation performance. This research focuses on methylation of $\mathrm{Hb}$ and its use as a renewable flocculant. The synthesized methylated hemoglobin

\footnotetext{
Correspondence to: M Essandoh, United States Department of Agriculture Agricultural Research Service, Eastern Regional Research Center, Biobased and Other Animal Coproducts Research Unit, 600 East Mermaid Lane, Wyndmoor PA 19038, USA. Email: Matthew.Essandoh@ars.usda.gov
}

Mention of trade names or commercial products in this publication is solely for the purpose of providing specific information and does not imply recommendation or endorsement by the U.S. Department of Agriculture. USDA is an equal opportunity provider and employer.

The authors declare no competing financial interest.

a United States Department of Agriculture, Agricultural Research Service, Eastern Regional Research Center, Biobased and Other Animal Coproducts Research Unit, Wyndmoor, PA, USA

b United States Department of Agriculture, Agricultural Research Service, Eastern Regional Research Center, Magnetic Resonance Facility - Core Technologies, Wyndmoor, PA, USA 
$(\mathrm{MeHb})$ is characterized systematically to provide an in-depth knowledge of the changes occurring after methylation, and is tested for its ability to promote the flocculation of clay at different $\mathrm{pH}$ values, settling times, and flocculant doses.

\section{EXPERIMENTAL}

\section{Materials}

Kaolin with the trade name 'Polygloss 90' from Huber Engineered Materials (Atlanta, GA, USA) was a gift from the MF Cachat Company (Lakewood, OH, USA). All other reagents and materials used in this study, including hemoglobin, were obtained from Sigma-Aldrich (St. Louis, MO, USA) unless otherwise specified. The hemoglobin used in this study was prepared from washed, lysed and dialyzed erythrocytes. Detailed descriptions of the preparation and processing of the $\mathrm{Hb}$ can be found on the manufacturers' website.

\section{Methylation procedure}

Methylation was carried out according to the method reported by Fraenkel-Conrat and Olcott (1945) with some modifications. ${ }^{9}$ In summary, $3 \%(\mathrm{w} / \mathrm{v})$ lyophilized bovine hemoglobin $(\mathrm{Hb})$ was suspended in methanol. Hydrochloric acid was added to the reaction medium so that the final concentration was $0.8 \mathrm{~mol} \mathrm{~L}^{-1}$. The sample was shaken continuously for $48 \mathrm{~h}$ at room temperature. The methylated bovine hemoglobin $(\mathrm{MeHb})$ was recovered by centrifugation at $10000 \times g$ for $15 \mathrm{~min}$. MeHb was then lyophilized and stored until needed.

\section{Degree of methylation analysis}

The degree of methylation was estimated following the protocol of Seki and Suzuki with modifications. ${ }^{7}$ Potentiometric titration was carried out using an autotitrator (Model 842, Metrohm Ltd, Herisau, Switzerland). The autotitrator was programmed to add the titrant until pH 11 (stop criterion) was achieved. In brief, $0.2 \mathrm{~g}$ of the $\mathrm{Hb}$ or MeHb were dissolved in $0.2 \mathrm{~L}$ of water, and then stirred continuously. The ionic strength of the solution was adjusted to $0.1 \mathrm{~mol} \mathrm{~L}^{-1}$ using $\mathrm{NaCl}$, before purging the sample under nitrogen environment for $30 \mathrm{~min}$. The titration was then performed (from $\mathrm{pH} 3$ to 11 ) using $0.1 \mathrm{~mol} \mathrm{~L}^{-1} \mathrm{NaOH}$ under nitrogen environment. The second derivative of the $\mathrm{pH}$ values vs volume $(\mathrm{mL})$ of $\mathrm{NaOH}$ used was plotted and the equivalence point was taken as the volume at which the second derivative was zero. The total carboxylic acid groups before and after methylation was used to estimate the extent of methylation using the formula below:

$$
T C A G=\frac{N \cdot V(45 / 1000)}{M}
$$

where $T C A G=$ total carboxylic acid group content $\left(\mathrm{mol} \mathrm{g} \mathrm{g}^{-1}\right)$; $N=$ concentration of the titrant $\left(\mathrm{mol} \mathrm{L}^{-1}\right) ; V=$ volume at the equivalence point $(\mathrm{L})$; and $M=$ mass of oven dried sample $(\mathrm{g})$.

\section{Quantification of hemoglobin in $\mathrm{Hb}$ and $\mathrm{MeHb}$}

The amount of hemoglobin was quantified in $\mathrm{Hb}$ and $\mathrm{MeHb}$ samples using the alkaline heamatin D-575 method with some slight modification. ${ }^{10}$ Briefly, alkaline haematin detergent 'AHD' reagent was prepared by adding $25 \mathrm{~g}$ of Triton-X 100 to $0.1 \mathrm{~mol} \mathrm{~L}^{-1}$ of $1 \mathrm{~L} \mathrm{NaOH}$. $20 \mu \mathrm{L}$ of a previously centrifuged $\mathrm{Hb}$ or MeHb solution was added to a test tube containing $3 \mathrm{~mL}$ of the 'AHD reagent'. The mixture was then vortexed and allowed to stand for about $5 \mathrm{~min}$ at room temperature. The absorbance at $575 \mathrm{~nm}$ was taken and the concentration was determined from a calibration graph prepared using a chlorohematin standard.

\section{Fourier transform infrared spectroscopy (FTIR) analysis}

The infrared spectra for both hemoglobin and methylated hemoglobin were obtained using a Thermo Nicolet 6700 FT-IR (Thermo Electron Corporation, Madison, WI, USA) spectrometer with DTGS detector. A total of 64 scans were taken from 4000 to $600 \mathrm{~cm}^{-1}$ with a resolution of $4 \mathrm{~cm}^{-1}$.

\section{Circular dichroism analysis}

A circular dichroism (CD) spectrometer (model 420, Biomedical Inc., Lakewood, NJ, USA) equipped with a photomultiplier tube was used to study the $\mathrm{Hb}$ and $\mathrm{MeHb}$ secondary structure content. The $C D$ spectra were taken using a sample concentration of $3 \mu \mathrm{mol}$ $\mathrm{L}^{-1}$ at $25^{\circ} \mathrm{C}$. The spectra were recorded with a bandwidth of 1 $\mathrm{nm}$ and an averaging time of $5 \mathrm{~s}$. A blank was also prepared for baseline correction. Samples were centrifuged at $5000 \times g$ for 5 min prior to analysis. A high transparency, $1 \mathrm{~mm}$ in path length quartz cell was used for the measurement. The CD spectra were recorded within the far UV region $(190-250 \mathrm{~nm})$ and the results are shown in molar ellipticity as a function of wavelength. All spectra were normalized by subtracting the baseline obtained for the blank.

\section{Nuclear magnetic resonance (NMR) procedure}

All spectra were acquired at $25^{\circ} \mathrm{C}$ in $\mathrm{D}_{2} \mathrm{O}$, with the sodium salt of 3-(trimethylsilyl)-propionic acid- $\mathrm{d}_{4}$ (TSP) added for signal referencing. Spectra of the MeHb were also acquired with the addition of $0.9 \% \mathrm{w} / \mathrm{v} \mathrm{NaCl}$ to enhance its solubility and a comparison spectrum was acquired under the same conditions for the non-methylated $\mathrm{Hb}$. Presaturation ${ }^{1} \mathrm{H}$ (proton) spectra of both samples were acquired using sweep-widths of 5205 at $400 \mathrm{MHz}$ and $9615 \mathrm{~Hz}$ at $600 \mathrm{MHz}$, using $32 \mathrm{k}$ data points, and were acquired with a $45^{\circ}$ pulse angle with a $30 \mathrm{~s}$ relaxation delay and a pre-saturation pulse of $1.5 \mathrm{~s}$. Solution-state NMR spectra were recorded at 14 Tesla on a VNMRS NMR spectrometer (Agilent Technologies, Santa Clara, CA, USA) using a $5 \mathrm{~mm}$ One NMR probe with z-axis pulsed field gradients. As the $\mathrm{MeHb}$ is flocculated in solution, adequate ${ }^{1} \mathrm{H}$ resolution could not be achieved by standard solution-state NMR. Instead, the pre-saturation ${ }^{1} \mathrm{H}$ spectrum was recorded at 9.4 Tesla on a Varian Inova NMR spectrometer (Palo Alto, CA, USA) using a $40 \mu \mathrm{L}$ MAS (magic-angle spinning) nanoprobe equipped $z$-axis pulsed field gradients. The resulting spectrum still suffers from significant line-broadening, but it is significantly improved over the standard solution state spectrum. The ${ }^{13} \mathrm{C}$ spectra of both samples were acquired in solution at $150 \mathrm{MHz}$, with a sweep-width of $37878 \mathrm{~Hz}$ and $64 \mathrm{k}$ data points, and were signal averaged over 50 000-100 000 transients, utilizing a $45^{\circ}$ pulse angle and a $1 \mathrm{~s}$ relaxation delay. The ${ }^{13} \mathrm{C}$ 135-DEPT (distortionless enhancement polarization transfer) experiments were acquired using the same parameters as the ${ }^{13} \mathrm{C}$ spectra, with the $\mathrm{C}-\mathrm{H}$ coupling constant set to $135 \mathrm{~Hz}$. The ${ }^{13} \mathrm{C}$ and ${ }^{13} \mathrm{C}$-DEPT spectra of the methylated sample have slightly broader linewidths, but are still interpretable due to the greater signal dispersion of the ${ }^{13} \mathrm{C}$ nucleus. Attempts to acquire HSQC or HMQC spectra of the methylated sample were unsuccessful due to the fast relaxation of the signal. All data were processed and baseline corrected using Agilent's VNMRJ 4.2 software. 


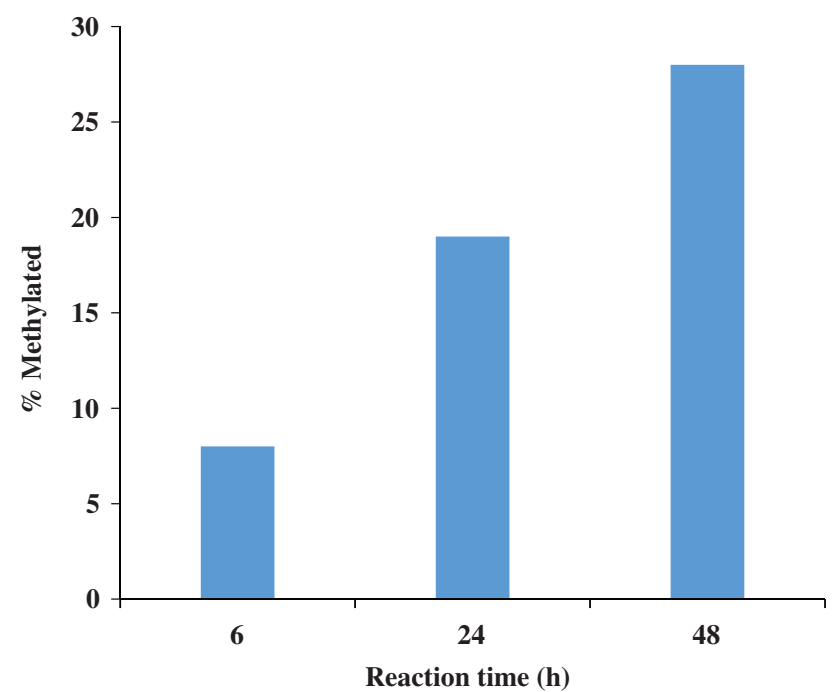

Figure 1. Percentage methylated when $3 \%(\mathrm{w} / \mathrm{v})$ lyophilized bovine hemoglobin $(\mathrm{Hb})$ was suspended in methanol containing 0.8 hydrochloric acid at room temperature.

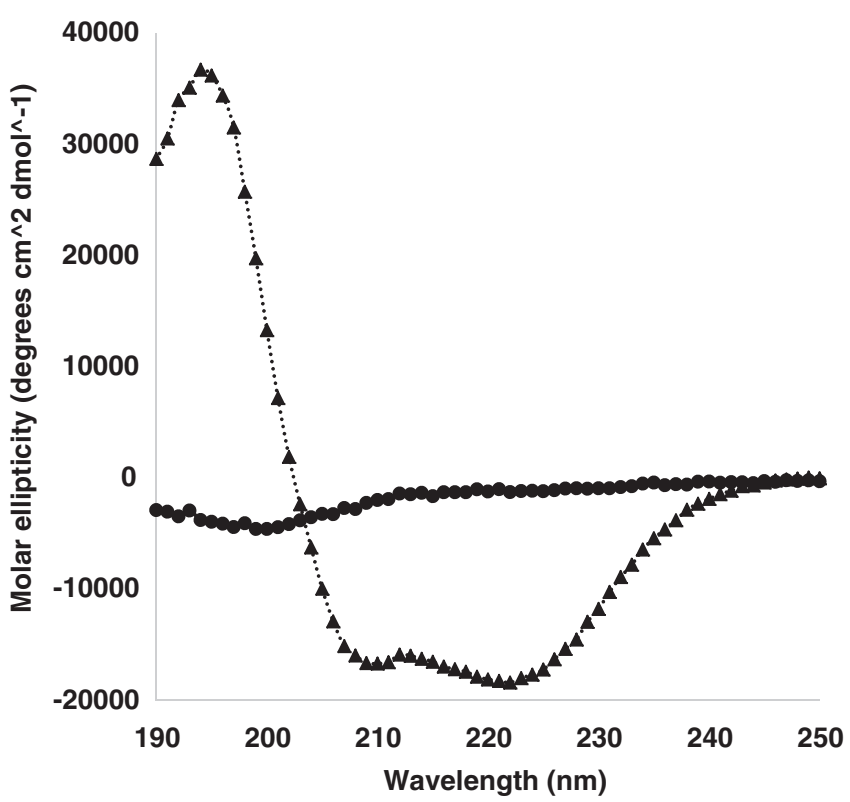

Figure 2. Circular dichroism spectra of $\mathrm{Hb}(\mathbf{\Delta})$ and $\mathrm{MeHb}(\boldsymbol{\bullet})$ in aqueous solution in the far UV region. Experimental conditions: temperature $25^{\circ} \mathrm{C}$ sample concentration $3 \mu \mathrm{mol} \mathrm{L}^{-1}$, bandwidth $1 \mathrm{~nm}$, averaging time $5 \mathrm{~s}$.

\section{Flocculation test with kaolin}

Flocculation experiments were carried out using a method which was designed in the author's lab for evaluation of experimental flocculants. ${ }^{11}$ Kaolin suspension of $3 \mathrm{~g} \mathrm{~L}^{-1}$ in $25 \mathrm{mmol} \mathrm{L}^{-1}$ Malic-MES-Tris buffer (MMT) at different pH (4.5 to 8.5) containing $0.01 \%$ thimerosal was prepared. Microorganisms may grow in intermediate $\mathrm{pH}$ buffers. Therefore, kaolin suspension can be stored in the refrigerator or $0.01 \%$ thimerosal can be added to prevent the growth of microorganisms. It is worth noting that the addition of $0.01 \%$ of thimerosal does not change the stability of the suspension. The initial turbidity of a $24 \mathrm{~mL}$ kaolin suspension was measured in a cylindrical glass vial with plastic caps. An appropriate aliquot of the flocculant was added and the suspension and flocculant were shaken at $400 \mathrm{rpm}$ for $1 \mathrm{~min}$ followed by $200 \mathrm{rpm}$

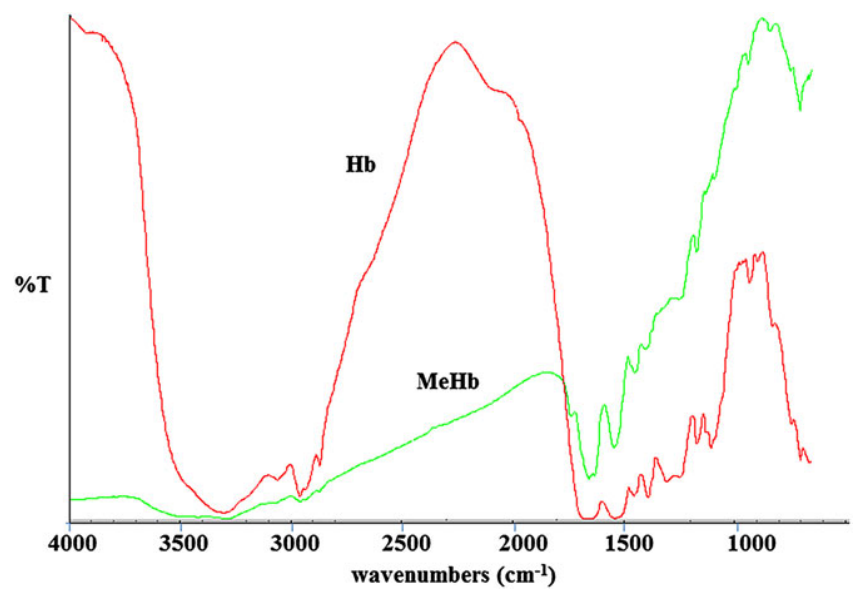

Figure 3. FTIR of $\mathrm{Hb}$ and $\mathrm{MeHb}$. A total of 64 scans were taken from 4000 to $600 \mathrm{~cm}^{-1}$ with a resolution of $4 \mathrm{~cm}^{-1}$.

for $15 \mathrm{~min}$. A control was also prepared in similar manner without the addition of the flocculant. The glass vials were placed in a tube rack and left undisturbed at $20 \pm 1^{\circ} \mathrm{C}$ for $6 \mathrm{~h}$ before measuring the final turbidity. Previously, we have found that the turbidity values are fairly constant after $6 \mathrm{~h}$. Therefore measurements were taken at $6 \mathrm{~h}$. A minimum of four replicates were prepared. Kaolin clarification effectiveness (KCE) was computed using:

$$
K C E_{(\text {Conditions })}=\log _{10}\left(\frac{T_{i}}{T_{f}}\right)
$$

where $T_{i}$ and $T_{f}$ are the initial and final turbidity, respectively, and the subscript (conditions) represent the standard conditions or the conditions used by the experimentalist. Standard deviation of KCE, $S_{K C E}$, was calculated using:

$$
S_{K C E}=\left(\frac{0.434}{\sqrt{n}}\right) \sqrt{\frac{s_{f}^{2}}{T_{f}^{2}}+\frac{s_{i}^{2}}{T_{i}^{2}}}
$$

where $s_{i}$ and $s_{f}$ are the standard deviations of the initial and final measurements, respectively, and $n$ is the number of replicates.

\section{RESULTS AND DISCUSSION}

\section{Degree of methylation}

When bovine hemoglobin ( $\mathrm{Hb}$ ) was esterified with methanol at different reaction times, different degrees of methylation were obtained. It has been reported that methylation is a specific reaction that affects only the carboxylic acid groups on proteins while other functional groups like indole, amino, phenolic, and thiol groups remain the same. ${ }^{9}$ The degree of methylation was quantified by potentiometric titration by comparing the total carboxylic acid groups before and after methylation. Figure 1 shows reaction times of 6,24 , and $48 \mathrm{~h}$ yielding $8 \%, 19 \%$, and $\sim 28 \%$ degree methylation, respectively. All subsequent studies were therefore done using the MeHb that was $\sim 28 \%$ methylated. This is comparable with prior work in which the extent of esterification of $\beta$-lactoglobulin was $14 \%$, $23 \%, 28 \%$, and $32 \%$ for reaction times of $16,24,48$, and $72 \mathrm{~h}$, respectively. ${ }^{12}$ 
(a)
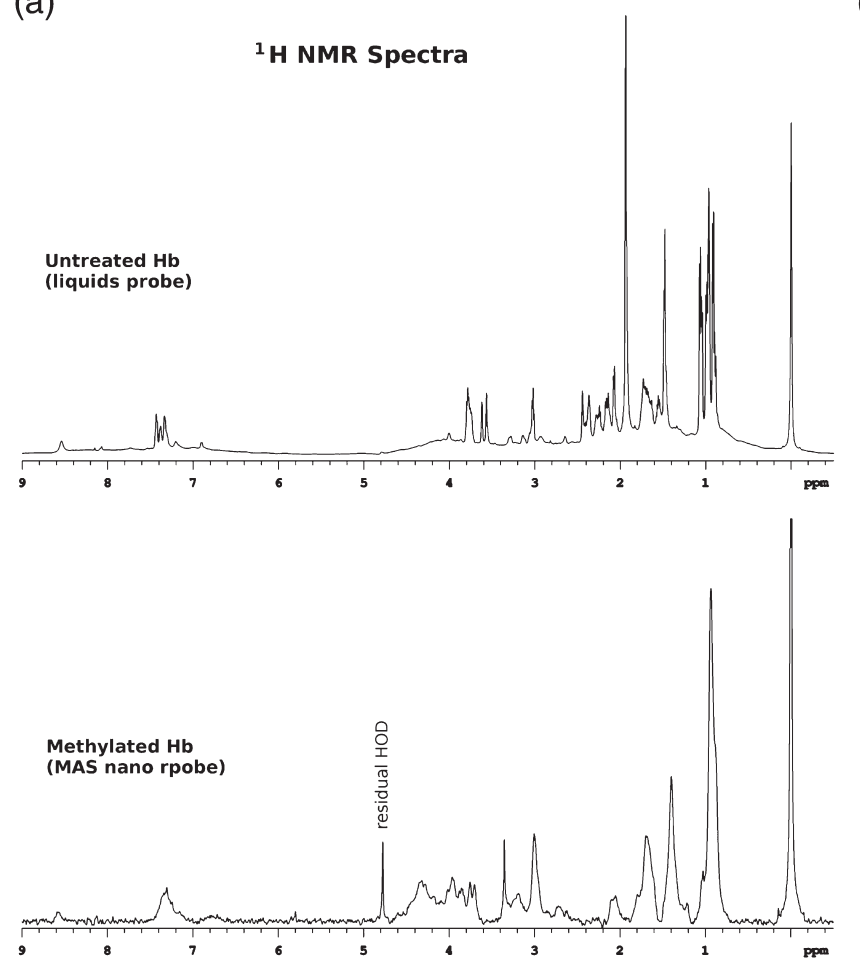

(b)

\section{${ }^{13}$ C 135-DEPT NMR Spectra}

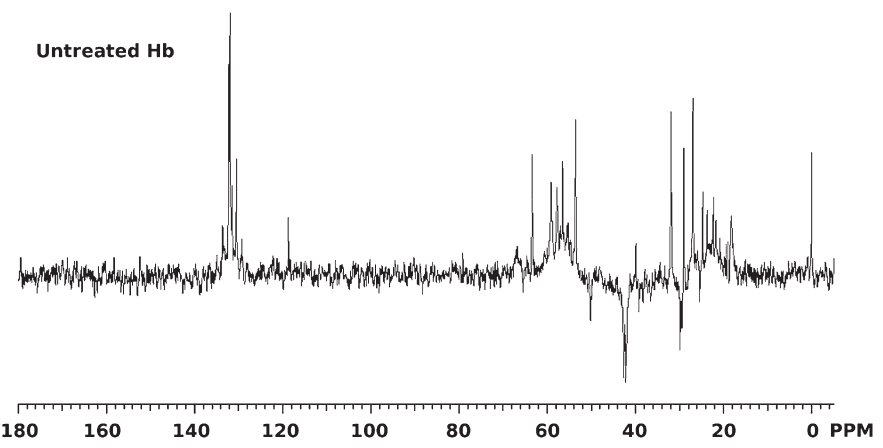

Figure 4. (a) ${ }^{1} \mathrm{H}$ NMR and (b) ${ }^{13} \mathrm{C}$ 135-DEPT NMR spectra of untreated $\mathrm{Hb}$ and methylated $\mathrm{Hb}$.

\section{Circular dichroism}

Circular dichroism (CD) was used to monitor any changes in the protein secondary structure contents. The formula below was used to convert the results obtained (ellipticity) into mean residue ellipticity (MRE), deg $\mathrm{cm}^{2} \mathrm{dmol}^{-1}$ or $\operatorname{deg~} \mathrm{M}^{-1} \mathrm{~cm}^{-1}$ :

$$
M R E=\frac{\theta_{o b s}}{c n l \times 10}
$$

Here, $\Theta o b s$ is the observed ellipticity in mdeg at $\lambda=222 \mathrm{~nm}$; $c$ is the concentration of the sample in molarity; $n$ is the number of amino acid residues in bovine $\mathrm{Hb}$; and $/$ is the path length of the cell in $\mathrm{cm}$. The CD spectra (Fig. 2) show changes in the protein secondary structure of $\mathrm{Hb}$ compared with $\mathrm{MeHb}$. The percentage of $\alpha$-helix in the pure $\mathrm{Hb}$ was $61 \%$. The $\alpha$-helix percentage content decrease to $8 \%$ upon methylation. The decrease in the $\alpha$-helix content is due to the unfolding or the perturbation of the secondary structure of the protein. The percentages of $\alpha$-helix, $\beta$-sheet, and random coil were $61 \%, 7 \%$, and $32 \%$, respectively, for the $\mathrm{Hb}$ using the $\mathrm{K} 2 \mathrm{~d}$ method. $^{13}$ The MeHb was composed of $8 \% \alpha$-helix, $48 \% \beta$-sheet, and $44 \%$ random coil. The structure of $\mathrm{Hb}$ is mainly dominated by $\alpha$-helix, while upon methylation the structure was dominated by $\beta$-sheet.

\section{Fourier transform infrared spectroscopy (FTIR)}

Successful methylation of $\mathrm{Hb}$ will result in the blocking of the carboxylic acid group and converting it to an ester functionality. Figure 3 shows the FTIR spectra for both the $\mathrm{Hb}$ and $\mathrm{MeHb}$. Both spectra show peaks at 2959 ( $\mathrm{C}-\mathrm{H}$ stretch), 1657 ( $\mathrm{C}=\mathrm{O}$ stretch), 1389 (O-H bend), 1304 (C-O stretch), and $931(\mathrm{O}-\mathrm{H}$ bend $) \mathrm{cm}^{-1}$. As expected, a closer look at the $\mathrm{OH}$ region shows the presence of a stronger and broader $\mathrm{OH}$ peak in $\mathrm{Hb}$ compared with the $\mathrm{MeHb}$. The change in the amount of $\mathrm{OH}$ peak was used to confirm whether methylation was achieved.

\section{NMR analysis}

While the ${ }^{1} \mathrm{H}$ spectrum of the unaltered $\mathrm{Hb}$ sample is sharp and highly resolved, the ${ }^{1} \mathrm{H}$ spectrum of the methylated sample, being slurry-like, remains somewhat broadened even under MAS conditions (Fig. 4(A)). Nevertheless, it is obvious that there are many significant differences between the spectra of $\mathrm{Hb}$ and $\mathrm{MeHb}$. While the majority of these differences are difficult to structurally identify it is clear that the ${ }^{1} \mathrm{H}$ spectrum of the MeHb sample has increased intensity between 3.5 and $4.6 \mathrm{ppm}$. This is probably due to higher concentrations of methoxy groups that are typically found in this spectral region. On the other hand, the non-methylated $\mathrm{Hb}$ sample has a tall, sharp peak at $1.93 \mathrm{ppm}$ in the ${ }^{1} \mathrm{H}$ spectrum which seems to vanish in the spectrum of MeHb. The identity of this peak is uncertain, and it may be that it has simply broadened and shifted in the spectrum of the methylated sample.

The solution-state ${ }^{13} \mathrm{C}$ spectra of the two samples (not shown for brevity) are difficult to compare because the slurry-like conditions of the MeHb sample resulted in extremely fast relaxation of the magnetization, producing a low quality spectrum with unreliable signal intensity.

The ${ }^{13} \mathrm{C}$ 135-DEPT spectra (Fig. 4(B)) provided not only better quality data, but also helpful insight into the ${ }^{13} \mathrm{C}$ spectra. This experiment allows one to determine the multiplicity of carbon atoms coupled to attached hydrogens: carbons with an odd number of attached hydrogens $\left(-\mathrm{CH}\right.$ - and $\left.-\mathrm{CH}_{3}\right)$ are phased positive, carbons with an even number of attached hydrogens $\left(-\mathrm{CH}_{2}-\right)$ are phased negative. In overlapping regions of both even and odd numbers of attached hydrogens, the signals tend to cancel. Since quaternary carbons are not detected the analysis is simplified. Alkyl methyl carbons appear below about $30 \mathrm{ppm}$, whereas $-\mathrm{CH}_{2}$ carbons occur between $\sim 20$ and 40 ppm, and signal cancellation occurs between $\sim 20$ and 30 ppm. For example, the greater linewidths of the methylated sample cause the negative peak at 


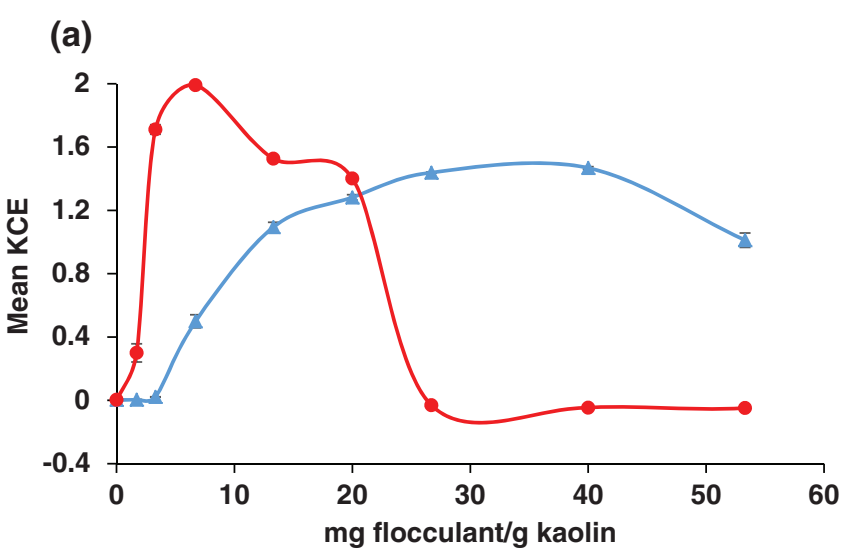

(b)

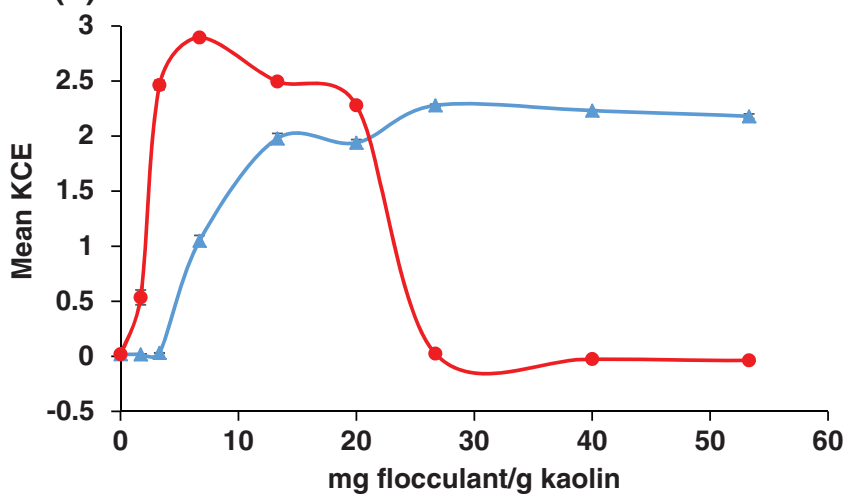

Figure 5. Effect of concentration on flocculation by $\mathrm{Hb}(\boldsymbol{\Lambda})$ and $\mathrm{MeHb}$ (•) at (a) $1 \mathrm{~h}$ settling time and (b) $6 \mathrm{~h}$ settling time. The concentration of Polygloss kaolin in the suspension was $3 \mathrm{~g} \mathrm{~L}^{-1}$ at $\mathrm{pH}$ 5.5. Data points are the mean $\pm S E, n=4$. Error bars are present for all points, but in most cases are too small to visualize.

$30 \mathrm{ppm}$ to cancel the intensity of the positive peak at $29 \mathrm{ppm}$, whereas both peaks can be observed in the sharper untreated sample. With that one exception, the region below $\sim 45 \mathrm{ppm}$ appears to be nearly the same for both samples. Conversely, the methoxy region ( $\sim 50-60 \mathrm{ppm})$ is more intense in the methylated sample, indicating an increase in the percentage of this functional group.

\section{Flocculation efficacy}

Flocculation studies were carried out using Polygloss 90 kaolin (a clay with the chemical formula $\mathrm{Al}_{2} \mathrm{O}_{3} \cdot 2 \mathrm{SiO}_{2} \cdot 2 \mathrm{H}_{2} \mathrm{O}$ ). The kaolin has a surface area of $22.0 \mathrm{~m}^{2} \mathrm{~g}^{-1}$ and is well known to exhibit a negative charge. The point of zero charge of kaolin has previously been determined to be in the range of 2.7 to $3.2,^{14,15}$ and thus kaolin should have a net negative surface charge over the entire $\mathrm{pH}$ range used in this study. The results of 1 and $6 \mathrm{~h}$ flocculation at different flocculant concentrations are shown in Fig. 5(a) and 5(b), respectively. Flocculant concentrations were varied from 0 to 55 mg flocculant per $\mathrm{g}$ kaolin while the kaolin suspension was held constant at $3 \mathrm{~g} \mathrm{~L}^{-1}$ and $\mathrm{pH}$ 5.5. As shown in Fig. 5(a), the kaolin clarification effectiveness (KCE) increases from $\sim 0$ to $\sim 1.47$ as the concentration was increased from 0 to $40 \mathrm{mg} \mathrm{g}^{-1}$ kaolin in the case of $\mathrm{Hb}$. Above $40 \mathrm{mg} \mathrm{g}^{-1}$ kaolin, the flocculation activity starts to decrease as is evident in the decrease in KCE at approximately 53 $\mathrm{mg} \mathrm{g}^{-1}$ kaolin. However, in the case of $\mathrm{MeHb}$, its KCE increased from $\sim 0$ to 2 as its concentration was raised from 0 to $\sim 6.6 \mathrm{mg} \mathrm{g}^{-1}$

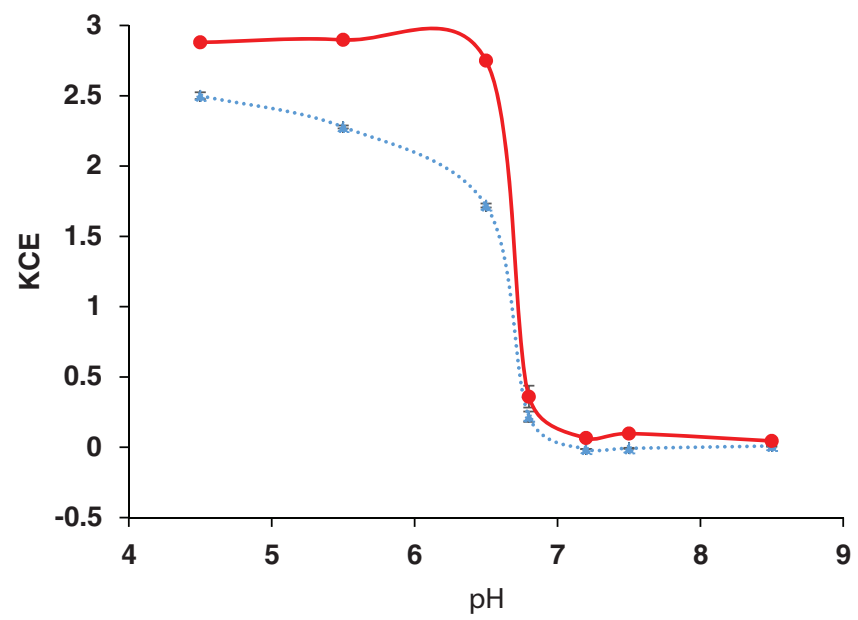

Figure 6. Effect of pH on flocculation by $\mathrm{Hb}(\boldsymbol{\Delta})$ and $\mathrm{MeHb}(\boldsymbol{\bullet})$ at $6 \mathrm{~h}$ settling time. The concentration of Polygloss kaolin in the suspension was $3 \mathrm{~g} \mathrm{~L}^{-1}$. The dose of flocculant used for the original $\mathrm{Hb}$ and $\mathrm{MeHb}$ samples were 27

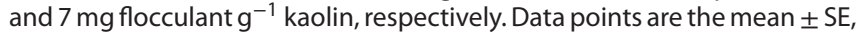
$\mathrm{n}=4$. Error bars are present for all points, but in most cases are too small to visualize.

kaolin. Above $20 \mathrm{mg} \mathrm{g}^{-1}$ kaolin, a decrease in flocculating activity is seen for the MeHb. Optimal clarification of kaolin was obtained within a concentration range of 0 to $20 \mathrm{mg} \mathrm{g}^{-1}$ kaolin. When higher than optimal doses of flocculant (27 to $53 \mathrm{mg} \mathrm{g}^{-1}$ kaolin) are used, the clarification effectiveness drops sharply. This may be due to the re-dispersion of kaolin in the suspension. It is not uncommon for flocculant performance to diminish when used at an excessively high dose. ${ }^{12}$ It is clear that the highest KCE at $1 \mathrm{~h}$ flocculation was achieved with $\mathrm{MeHb}$ at the concentration of $\sim 6.6 \mathrm{mg} \mathrm{g}^{-1}$ kaolin.

At $6 \mathrm{~h}$ flocculation time (Fig. 5(b)), the KCE for $\mathrm{Hb}$ remains fairly constant from 13 to $53 \mathrm{mg} \mathrm{g}^{-1}$ kaolin, with the highest KCE achieved when the concentration is $27 \mathrm{mg} \mathrm{g}^{-1}$. In the case of $\mathrm{MeHb}$, there is a sharp drop in KCE above $13 \mathrm{mg} \mathrm{g}^{-1}$ kaolin. The MeHb KCE values were $\geq 2.3$ from 3.3 to $20 \mathrm{mg} \mathrm{g}^{-1}$ kaolin, with the highest value obtained at a concentration of $3.3 \mathrm{mg} \mathrm{g}^{-1}$ kaolin. It is interesting to note that, at $\mathrm{pH} 5.5$, the amount of hemoglobin needed to achieve approximately the same clarification effectiveness was four times higher in the $\mathrm{Hb}$ compared with MeHb. These differences in KCE results between $\mathrm{MeHb}$ and $\mathrm{Hb}$ are quite large since KCE is a logarithmic scale. For example, a KCE of 3 represents a 1000-fold decrease in turbidity while a KCE of 2 shows that the decrease in turbidity was 100-fold.

The effect of $\mathrm{pH}$ on flocculant performance is shown in Fig. 6. The isoelectric point of $\mathrm{Hb}$ and methylated $\mathrm{Hb}$ determined using Zetasizer Nano were found to be 6 and 8, respectively, (not shown for brevity). As expected, the esterification of carboxyl groups should have the effect of raising the pl. It is well known that lower $\mathrm{pH}$ values results in net positive charge on proteins. At lower $\mathrm{pH}$ values (that is $\mathrm{pH}$ less than the $\mathrm{pl}$ of the flocculants), both $\mathrm{Hb}$ and $\mathrm{MeHb}$ are positively charged while the kaolin is negatively charged. Therefore, when the kaolin suspension is mixed with $\mathrm{Hb}$ or $\mathrm{MeHb}$, there is enhanced flocculation as a result of the electrostatic attraction between the positively charged flocculant and the negatively charged kaolin. The flocculants bind to the kaolin, forming flocs, resulting in significant flocculation at lower $\mathrm{pH}$ values. 
At $\mathrm{pH}$ above 6.5 in the case of $\mathrm{Hb}$, the flocculation activity decreases sharply. The $\mathrm{pl}$ of $\mathrm{Hb}$ is 6 . At $\mathrm{pH}$ above the $\mathrm{pl}$, $\mathrm{Hb}$ acquires a net negative charge. That is, at higher $\mathrm{pH}$ values ( $\mathrm{pH}$ greater than the $\mathrm{pl}$ of the flocculant), both the kaolin and flocculant are negatively charged. By methylating the carboxylic acid groups on the protein, the number of negatively charged spots on the protein is reduced. This subsequently diminishes the repulsion between $\mathrm{MeHb}$ and the negative charges on the kaolin surface. It is therefore not surprising that the KCE for $\mathrm{Hb}$ starts to decrease even at $\mathrm{pH} 6.5$ while that for the MeHb remains approximately constant (Fig. 6). The percentage of original turbidity removed was $37 \%$ for $\mathrm{Hb}$ while $60 \%$ of the original turbidity was removed for $\mathrm{MeHb}$ at near-neutral $\mathrm{pH}(\mathrm{pH}=6.8)$. $\mathrm{Hb}$ actually increased the turbidity of the suspension, above its initial turbidity at all $\mathrm{pH}$ values above 6.8; this negative effect was never observed for MeHb. Other authors have shown that methylated egg albumin and soy protein can effectively flocculate diatomite particles over a broad $\mathrm{pH}$ range from 3 to $10 .^{7,8}$ Nonetheless, it is clear that $\mathrm{MeHb}$ is a better flocculant at higher $\mathrm{pH}$ than $\mathrm{Hb}$ because of the increase in the net positive charge resulting from the blocking of the carboxylic acid groups during methylation.

We point out that it is very hard to make meaningful general comparisons with commercial polymeric flocculants such as polyacrylamide (PAM). Even within a single supplier of PAM flocculants, many varieties are available, and the manufacturer treats chemical characteristics of each preparation as proprietary information. In any particular practical or experimental situation, different varieties of PAM will perform differently.

\section{CONCLUSIONS}

Bovine $\mathrm{Hb}$, an inexpensive bioflocculant, has been covalently modified to improve its flocculation activity. MeHb was characterized using different analytical techniques to monitor and confirm the intended change. The flocculant performances of $\mathrm{Hb}$ and $\mathrm{MeHb}$ were tested with kaolin suspensions at different $\mathrm{pH}$ values, settling times, and flocculant doses. At higher $\mathrm{pH}$ values (>5.5), MeHb showed better flocculating activity than $\mathrm{Hb}$, making $\mathrm{MeHb}$ a more useful industrial flocculant than $\mathrm{Hb}$. Another advantage of $\mathrm{MeHb}$ over $\mathrm{Hb}$ is that, under some conditions, $\mathrm{MeHb}$ clarified suspensions of kaolin at one-quarter the dose of that required by $\mathrm{Hb}$.

\section{REFERENCES}

1 Luo Y-L, Yang Z-H, Xu Z-Y, Zhou L-J, Zeng G-M, Huang J et al., Effect of trace amounts of polyacrylamide (PAM) on long-term performance of activated sludge. J Hazard Mater 189:69-75 (2011).

2 Molak $\mathrm{V}, \mathrm{NIOH}$ and $\mathrm{NIOSH}$ basis for an occupational health standard. Acrylamide: a Review of the Literature Atlanta, Georgia: US Department of Health and Human Services (1991).

3 Touzé S, Guerin V, Guezennec A-G, Binet S and Togola A, Dissemination of acrylamide monomer from polyacrylamide-based flocculant use - sand and gravel quarry case study. Environ Sci Pollut $R$ 22:6423-6430 (2015).

4 Quint RJ, Use of polyacrylamide (PAM) in the Bureau of Reclamation canals to reduce seepage losses. Report from Bureau of Reclamation, United States Department of the Interior (2007).

5 Del Hoyo P, Moure F, Rendueles M and Diaz M, Demineralization of animal blood plasma by ion exchange and ultrafiltration. Meat Sci 76:402-410 (2007).

6 Piazza GJ, Lora JH and Garcia RA, Flocculation of kaolin and lignin by bovine blood and hemoglobin. J Chem Technol Biotechnol 90:1419-1425 (2015).

7 Seki $\mathrm{H}$ and Suzuki A, Flocculation of diatomite by methylated egg albumin. J Colloid Interface Sci 263:42-46 (2003).

8 Seki $\mathrm{H}$, Maruyama $\mathrm{H}$ and Shoji $\mathrm{Y}$, Flocculation of diatomite by a soy protein-based bioflocculant. Biochem Eng J 51:14-18 (2010).

9 Fraenkel-Conrat $\mathrm{H}$ and Olcott HS, Esterification of proteins with alcohols of low molecular weight. J Biol Chem 161:259-268 (1945).

10 Zander R, Lang W and Wolf HU, Alkaline haematin D-575, a new tool for the determination of haemoglobin as an alternative to the cyanhaemiglobin method. I. Description of the method. Clin Chim Acta 136:83-93 (1984).

11 Garcia RA, Riner SA and Piazza GJ, Design of a laboratory method for rapid evaluation of experimental flocculants. Ind Eng Chem Res 53:880-886 (2013).

12 Sitohy M, Chobert J and Haertle T, Study of factors influencing protein esterification using $\beta$-lactoglobulin as a model. J Food Biochem 24:381-398 (2000).

13 Sreerama N and Woody RW, Estimation of protein secondary structure from circular dichroism spectra: Comparison of CONTIN, SELCON, and CDSSTR methods with an expanded reference set. Anal Biochem 287:252-260 (2000).

14 Kwawmee K, Suddhiprakarn A, Kheoruenromne I and Singh B, Surface charge properties of kaolinet from Thai soils. Geoderma 192:120-131 (2013).

15 Appel C, Ma QL, Rhue RD and Kennelley E, Point of zero charge determination in soils and minerals via traditional methods and detection of electroacoustic mobility. Geoderma 113:77-93 (2003). 